\title{
Intra-operative periarticular multimodal injection in total knee arthroplasty: a local hospital experience in Hong Kong
}

\author{
Jason CH Fan *
}

This article was published on $14 \mathrm{Mar}$ 2018 at www.hkmj.org.

\section{A B S T R A C T}

Introduction: Data from a local report revealed the superior outcome of regional anaesthesia and analgesia compared with general anaesthesia and intravenous patient-controlled analgesia in total knee arthroplasty. This retrospective study aimed to assess the efficacy of intra-operative periarticular multimodal injection in improving postoperative pain and reducing morphine consumption with patient-controlled analgesia after total knee arthroplasty in patients with knee osteoarthritis.

Methods: From July 2005 to May 2009, 213 total knee arthroplasties without intra-operative periarticular multimodal injection (control group) were performed at a local hospital. From June 2009 to December 2012, 185 total knee arthroplasties were performed with intra-operative periarticular multimodal injection (cocktail group). The inclusion criteria were osteoarthritis of the knee, single method of anaesthesia (general or neuraxial), simple total knee arthroplasty without any metal augmentation or constraint, and postoperative patient-controlled analgesia. Postoperative patient- controlled morphine doses were compared.

Results: A total of 152 total knee arthroplasties were recruited to the cocktail group, and 89 to the control group. Duration of tourniquet application and preoperative knee score did not significantly correlate with morphine consumption by patientcontrolled analgesia. Multimodal injection significantly decreased such consumption for $36 \mathrm{~h}$. When injection was separately analysed for general and neuraxial anaesthesia, the effect lasted for $42 \mathrm{~h}$ and $24 \mathrm{~h}$, respectively.

Conclusion: Intra-operative periarticular multimodal injection decreased morphine consumption for up to $42 \mathrm{~h}$ postoperatively.

\section{Hong Kong Med J 2018;24:145-51}

DOI: 10.12809/hkmj176804

JCH Fan *, FHKAM (Orthopaedic Surgery)

Department of Orthopaedics and Traumatology, Alice Ho Miu Ling Nethersole Hospital, Tai Po, Hong Kong

* Corresponding author: fchjason@gmail.com

New knowledge added by this study

- Intra-operative periarticular multimodal injection in total knee arthroplasty could decrease parenteral morphine consumption for up to 42 hours.

Implications for clinical practice or policy

- Intra-operative periarticular multimodal injection should be adopted as a standard local practice for postoperative pain control. This practice may be extended to operations other than total knee arthroplasty.

\section{Introduction}

Postoperative pain following total knee arthroplasty (TKA) is reported to be severe in approximately $60 \%$ of patients and moderate in approximately $30 \% .{ }^{1}$ It is associated with arthrofibrosis and diminished range of motion. ${ }^{2,3}$ Good pain relief is important for rehabilitation following TKA. ${ }^{4}$ Many modes of perioperative and postoperative analgesia are available, and involve various combinations of systemic and regional analgesia. Intra-operative periarticular multimodal drug injection has been well documented as an excellent method to alleviate postoperative pain following TKA..$^{5-7}$ Nonetheless, a previous retrospective study $y^{5}$ and a randomised trial $^{6}$ that analysed two different groups of patients with multiple diagnoses and multiple anaesthetic methods revealed that the effect of periarticular injection might have been affected by different causes of end-stage arthritis leading to TKA. Different anaesthetic methods could also have affected patients' perception of pain and parenteral morphine consumption.

In 2006, Chu et $\mathrm{al}^{8}$ reported the superior outcome of regional anaesthesia and regionally delivered analgesia compared with general anaesthesia (GA) and intravenous patient-controlled analgesia (PCA) in TKA at the Alice Ho Miu Ling Nethersole Hospital (AHNH). Since June 2009, intra-operative periarticular multimodal injection (IPMI) consisting of an opioid (morphine), a long- 


\section{全膝關節置換術中關節周圍多模式注射：香港 一所醫院的經驗 \\ 范智豪}

引言：本地報告的數據顯示, 與全身麻醉和全膝關節置換術中的靜脈 自控鎮痛比較, 局部麻醉有較佳鎮痛效果。本研究旨在評估術中關節 周圍多模式注射的療效, 在改善術後疼痛控制和減少退化性膝關節炎 患者全膝關節置換術（TKA）後患者自控鎮痛的嗎啡用量。

方法：2005年7月至2009年5月期間, 一間本地醫院有 213 例無採納多 模式注射的TKA（對照組）。在2009年6月至2012年12月期間，我們 進行了 185 例配有多模式注射的TKA（實驗組）。研究納入標準為患 者有退化性膝關節, 使用全身麻醉或神經軸麻醉的單一麻醉方法, 無 任何金屬增加或約束的簡單TKA, 以及術後患者使用自控鎮痛。研究 也比較各組術後自控鎮痛的嗎啡用量。

結果：實驗組有 152 例，對照組有89例。未有發現止血帶應用持續時 間和術前膝關節評分與患者自控鎮痛的嗎啡用量顯著相關。術後36小 時內, 多模式注射液能顯著降低自控鎮痛的嗎啡用量。經全身麻醉的 患者的功效可以維持42小時, 而經神經軸麻醉的患者可以維持 24 小 時。

結論：術中關節周圍多模式注射能有效減少全膝關節置換術後嗎啡的 使用，最多長達42小時。 acting local anaesthetic (levobupivacaine) and epinephrine, has been administered by surgeons to control postoperative pain following TKA. This retrospective cohort study analysed the efficacy of IPMI in TKA and also its effect following different types of anaesthesia.

\section{Methods}

\section{Perioperative pain management}

Before June 2009, postoperative pain following primary TKA was managed by a combination of parenteral and oral analgesia. The anaesthetist determined the choice of parenteral analgesia that included regular or as-required subcutaneous morphine injection, PCA with intravenous morphine injection, or epidural analgesia (EpA). Oral paracetamol $1 \mathrm{~g}$ every $6 \mathrm{~h}$ was prescribed to all patients from day 1 to 3 . Since June 2009, IPMI has been routinely added, and comprises $20 \mathrm{~mL}$ of $0.5 \%$ levobupivacaine, $1 \mathrm{~mL}$ of $5 \mathrm{mg} / \mathrm{mL}$ morphine, $2 \mathrm{~mL}$ of $1: 10000$ adrenaline, and $17 \mathrm{~mL}$ of normal saline. In this study, half of this $40-\mathrm{mL}$ mixture was injected into the posterior capsule, collaterals, and quadriceps incision before implantation of the prosthesis. The other half was injected into the subcutaneous tissue after suturing of the arthrotomy. All patients with PCA were assessed hourly for the first $24 \mathrm{~h}$ to monitor vital signs, pain score, and patient-controlled analgesia morphine consumption (PCAMC), and thereafter every $6 \mathrm{~h}$ for 2 more days.

\section{Patient selection}

From July 2005 to May 2009, 213 TKAs without IPMI (control group) were performed at AHNH. They included 196 knees with osteoarthritis (OA) and 17 knees with rheumatoid arthritis. From June 2009 to December 2012, 185 TKAs were performed with IPMI (cocktail group). There were 175 OA knees, nine rheumatoid arthritis knees, and one Charcot knee.

All TKAs were performed through an anterior midline incision and medial parapatellar arthrotomy with tourniquet pressure of $300 \mathrm{~mm} \mathrm{Hg}$. A cemented posterior stabilised model was used in all cases except for two cases in the control group and nine cases in the cocktail group where a semiconstrained TKA was performed. All operations were performed under GA or neuraxial anaesthesia $(\mathrm{NeA})$ that was either combined spinal epidural or spinal anaesthesia. Four TKAs in the cocktail group and four in the control group were performed with combined GA and NeA. A closed-suction surgical drain was inserted and was routinely removed on postoperative day 2 .

For postoperative pain control in the control group, PCA was used in 112 TKAs, EpA in 66 TKAs, and subcutaneous morphine injections in 10 TKAs. A 4-point pain scale was completed by a pain nurse to assess pain in 189 PCA patients before October 2008 and a 10-point pain scale used in 23 PCA patients thereafter. In the cocktail group, 152 TKAs were managed with PCA, three with EpA, and three with subcutaneous morphine injections. Pain in all PCA patients was assessed by a 10-point pain scale.

The inclusion criteria for this study were OA of the knee, single method of anaesthesia of either GA or NeA, simple TKA without any metal augmentation or constraint, and postoperative PCA. The patients in the control group who were assessed by the 10-point pain scale were excluded to ensure a common pain assessment tool for each group.

\section{Method of data retrieval, analysis, and study hypothesis}

This was a retrospective cohort observational study carried out in accordance with the principles outlined in the Declaration of Helsinki. Informed patient consent was not required because it was a record-based study that revealed no individual identities or sensitive individual information. The medical records and electronic patient records were traced and the necessary data-including demographic data, TKA model and anaesthetic method, first 72-hour pain score and morphine consumption, and postoperative complicationswere entered into an electronic file by a single member of staff blinded to the study hypothesis. The accuracy of the data was selectively double-checked 


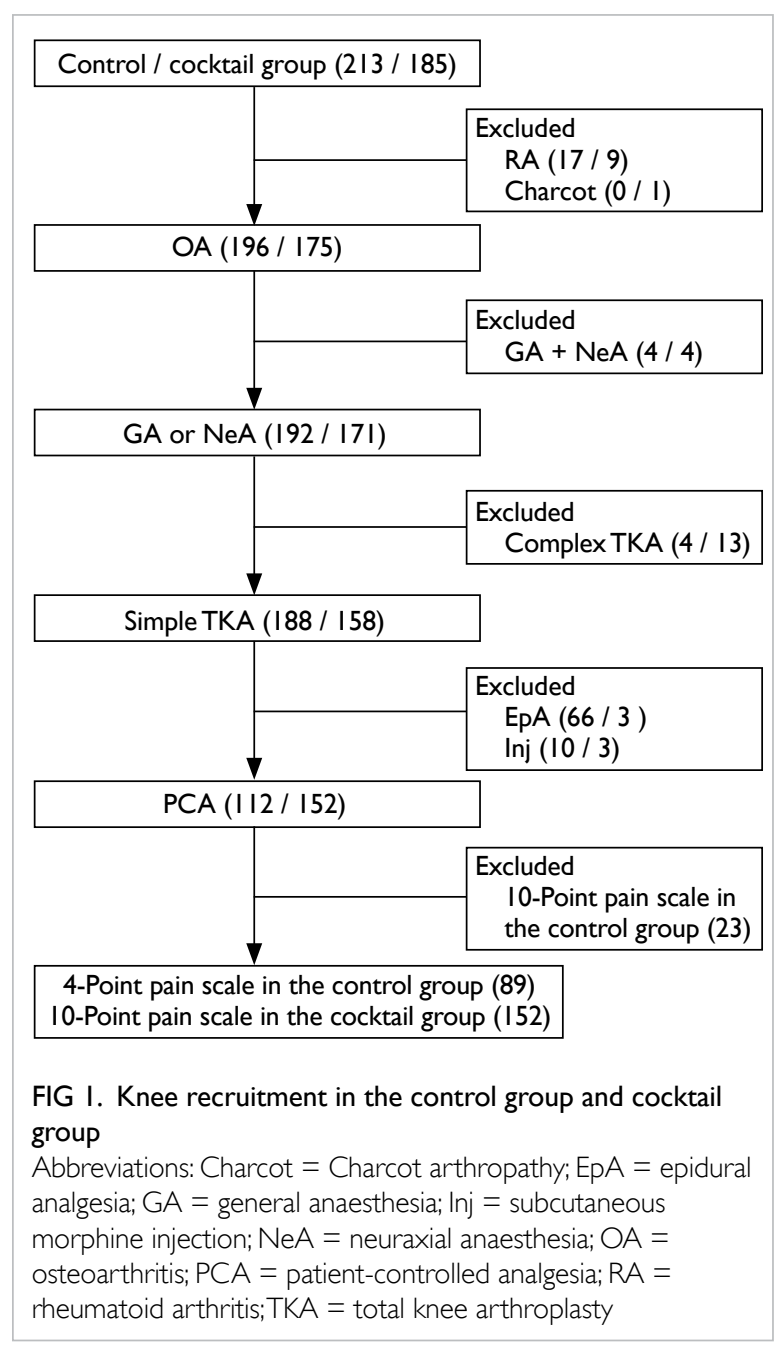

by the author. To enable comparison, pain score was divided by 4 when the 4-point scale was used and by 10 for the 10-point scale. Statistical Package for the Social Sciences (Windows version 13.0; SPSS Inc, Chicago [IL], United States) was used for analysis. The null hypothesis was that IPMI would not alleviate postoperative pain and would not reduce PCAMC. The Chi squared test and two-tailed independent $t$ test were used to analyse categorical and continuous data, respectively. The Pearson correlation test was used to detect any relationship between cumulative PCAMC and tourniquet time, and between PCAMC and preoperative knee score. Statistical significance was set at $\mathrm{P}<0.05$.

\section{Results}

\section{Perioperative variables}

A total of 152 knees (134 patients) in the cocktail group and 89 knees (76 patients) in the control group were recruited (Fig 1). Table 1 shows the demographic data and clinical characteristics of patients, and Table 2 shows the models of primary
TABLE I. Patient and clinical characteristics, by study group

\begin{tabular}{|c|c|c|}
\hline \multirow[t]{2}{*}{ Characteristics } & \multicolumn{2}{|c|}{$\begin{array}{c}\text { Value, } \\
\text { mean (range) } \\
\text { [unless otherwise stated] }\end{array}$} \\
\hline & Cocktail group & Control group \\
\hline No. of patients/knees & $134 / 152$ & $76 / 89$ \\
\hline \multicolumn{3}{|l|}{ Age } \\
\hline Overall & $68.9(53-84)$ & $67.4(44-82)$ \\
\hline GA & $67.5(53-82)$ & $66.1(44-80)$ \\
\hline $\mathrm{NeA}$ & $69.8(55-84)$ & $69.1(53-82)$ \\
\hline \multicolumn{3}{|l|}{ Sex (female/male) } \\
\hline Overall & $100 / 34$ & $59 / 17$ \\
\hline GA & $40 / 15$ & $31 / 9$ \\
\hline $\mathrm{NeA}$ & $60 / 19$ & $28 / 8$ \\
\hline \multicolumn{3}{|l|}{ Left/right knee } \\
\hline Overall & $78 / 74$ & $43 / 46$ \\
\hline GA & $35 / 25$ & $23 / 26$ \\
\hline $\mathrm{NeA}$ & $43 / 49$ & $20 / 20$ \\
\hline \multicolumn{3}{|l|}{ Knee score } \\
\hline Overall & $39.5(0-76)$ & $36.8(8-77)$ \\
\hline GA & $38.2(10-69)$ & $37.0(19-69)$ \\
\hline $\mathrm{NeA}$ & $40.4(0-76)$ & $36.5(8-77)$ \\
\hline \multicolumn{3}{|l|}{ Function score } \\
\hline Overall & $47.6(0-100)$ & $47.4(0-80)$ \\
\hline GA & $46.0(0-80)$ & $46.1(0-80)$ \\
\hline $\mathrm{NeA}$ & $48.6(0-100)$ & $49.0(0-75)$ \\
\hline \multicolumn{3}{|l|}{ Tourniquet time (min) } \\
\hline Overall & $105.5(22-191)$ & $116.4(13-160)^{\star}$ \\
\hline GA & $108.0(22-191)$ & $118.4(64-160) \dagger$ \\
\hline $\mathrm{NeA}$ & $103.9(25-157)$ & $113.9(13-146) \ddagger$ \\
\hline
\end{tabular}

Abbreviations: $\mathrm{GA}$ = general anaesthesia; $\mathrm{NeA}=$ neuraxial anaesthesia including spinal anaesthesia and combined spinal epidural anaesthesia

* $\mathrm{P}=0.001$

$+P=0.029$

‡ $\mathrm{P}=0.024$

TKAs and anaesthetic methods. There was no statistically significant difference in age, sex, the side operated on, and mean preoperative knee score or function score between the cocktail and control groups. Tourniquet time was significantly longer in the control group $(\mathrm{P}<0.05)$. There was no correlation between tourniquet time and PCAMC for any postoperative period (all correlation coefficients $<0.1$ and $P>0.05$ ). This indicated that tourniquet time was not confounding. Preoperative knee score was not correlated with PCAMC (all correlation coefficients $<0.2$ and $P>0.05)$. Comparison of the number of Press Fit Condylar Sigma and non-Press Fit Condylar models between the two groups revealed a statistical significance $(\mathrm{P}<0.001)$. However, all these models substitute for the posterior cruciate ligament and 
TABLE 2. Total knee arthroplasty model and anaesthesia, by study group

\begin{tabular}{lcc}
\hline & Cocktail group & Control group \\
\hline Model & 96 & 88 \\
\hline Press Fit Condylar Sigma (Depuy) & 50 & 1 \\
Nexgen (Zimmer) & 3 & 0 \\
\hline Triathlon (Stryker) & 3 & 0 \\
Genesis II (Smith \& Nephew) & & \\
Anaesthesia & 60 & 63 \\
General & 50 & 20 \\
Spinal & 42 & 6 \\
\hline Combined spinal epidural & & \\
\hline
\end{tabular}

have a similar design. They were all used in primary simple TKA, and model type would not have caused any difference in early postoperative pain perception.

\section{Cumulative patient-controlled analgesia morphine consumption}

The mean cumulative PCAMC in both the cocktail and control groups increased gradually until $72 \mathrm{~h}$ postoperatively (Fig 2). The difference between the two groups reached statistical significance in the first $36 \mathrm{~h}$. When effects of GA and NeA were reviewed separately, significantly less PCA morphine was required in the cocktail group than in the control group for the first $42 \mathrm{~h}$ (after GA) and $24 \mathrm{~h}$ (after $\mathrm{NeA})$.

\section{Pain scale and complication}

Figure 3 shows a decreasing severity of pain for both groups in the initial $72 \mathrm{~h}$ after surgery. There was no statistically significant difference between groups when TKA was performed under GA. In patients who underwent TKA under NeA, patients in the control group had a lower pain scale score by 0.1 at $12 \mathrm{~h}$ and from 24 to $48 \mathrm{~h}$ compared with the cocktail group, although this was gradually reversed up to $72 \mathrm{~h}$. There were no adverse effects or complications as a result of IPMI.

\section{Discussion}

Severe pain following TKA may be related to bone or soft tissue trauma or hyperperfusion following tourniquet release. ${ }^{6}$ Surgical difficulty in TKA has also been found to be related to postoperative pain ${ }^{9}$ and related to bone loss, severe deformity, flexion contracture, and poor range, all of which contribute to a low preoperative knee score. Nonetheless, in this study, the duration of tourniquet application was not significantly correlated with morphine consumption; and preoperative knee score was not correlated with PCAMC.

Pain management for TKA should start preoperatively and intra-operatively. The preemptive use of analgesia has been shown to prevent central sensitisation and improve postoperative pain control. ${ }^{10-12}$ Busch et $\mathrm{al}^{6}$ conducted a randomised trial of periarticular multimodal drug injection of ropivacaine, ketorolac, epimorphine, and epinephrine in 64 TKA patients. They reported significantly lower pain scores, increased patient satisfaction scores, and decreased requirement for PCA in the first 24 hours after surgery. In another randomised trial of periarticular injection of bupivacaine, fentanyl, and methylprednisolone in either side of bilateral TKAs in 40 patients, pain scores were significantly lower, and active knee flexion ranges were greater until the fourth week after surgery. ${ }^{13}$ Maheshwari et $\mathrm{al}^{7}$ emphasised the importance of periarticular injection in multimodal pain management following TKA at the Ranawat Orthopaedic Center, United States, and PCA was no longer used because of the high rates of systemic opioid side-effects.

The AHNH includes morphine in multimodal injections because opioid receptors are present in peripheral inflamed tissue. ${ }^{14,15}$ They are expressed within hours of surgical trauma and are thought to be responsible for afferent sensory input to the central nervous system. ${ }^{16,17}$ The injection also includes levobupivacaine, which is pharmacokinetically similar to bupivacaine. It is a pure left-isomer and has less cardiac and central nervous system toxicity. ${ }^{18}$ Corticosteroid was not added to the injection, although studies ${ }^{19,20}$ have shown that methylprednisolone in periarticular injections in total joint surgeries caused no delayed wound healing or wound infection. Mullaji et $\mathrm{al}^{13}$ advocated cautious use of steroid for fear of increasing the risk of surgical site infection in patients who (1) had prior open surgical procedures, (2) were undergoing revision TKA, (3) had poor nutritional status, (4) were immunocompromised, (5) were rheumatoid, or (6) were diabetic. In the current study, periarticular injection of a specific mixture decreased PCAMC for up to 42 hours. In 2013, Andersen et $\mathrm{al}^{21}$ advocated the addition of ketorolac during local infiltration analgesia. They prepared the medication by mixing $150 \mathrm{~mL}$ of ropivacaine $2 \mathrm{mg} / \mathrm{mL}$ with $1 \mathrm{~mL}$ of ketorolac $30 \mathrm{mg} / \mathrm{mL}$; to $100 \mathrm{~mL}$ of this mixture was added $0.5 \mathrm{~mL}$ of epinephrine $1 \mathrm{mg} / \mathrm{mL}$. The mixture containing epinephrine was injected into the posterior capsule and around the prosthesis, and the $50 \mathrm{~mL}$ without epinephrine was injected into the fascia and subcutis. An intra-articular catheter was left in place to enable eight postoperative bolus injections of analgesic without epinephrine. It was found that ketorolac successfully reduced morphine consumption, pain intensity, and length of hospital 

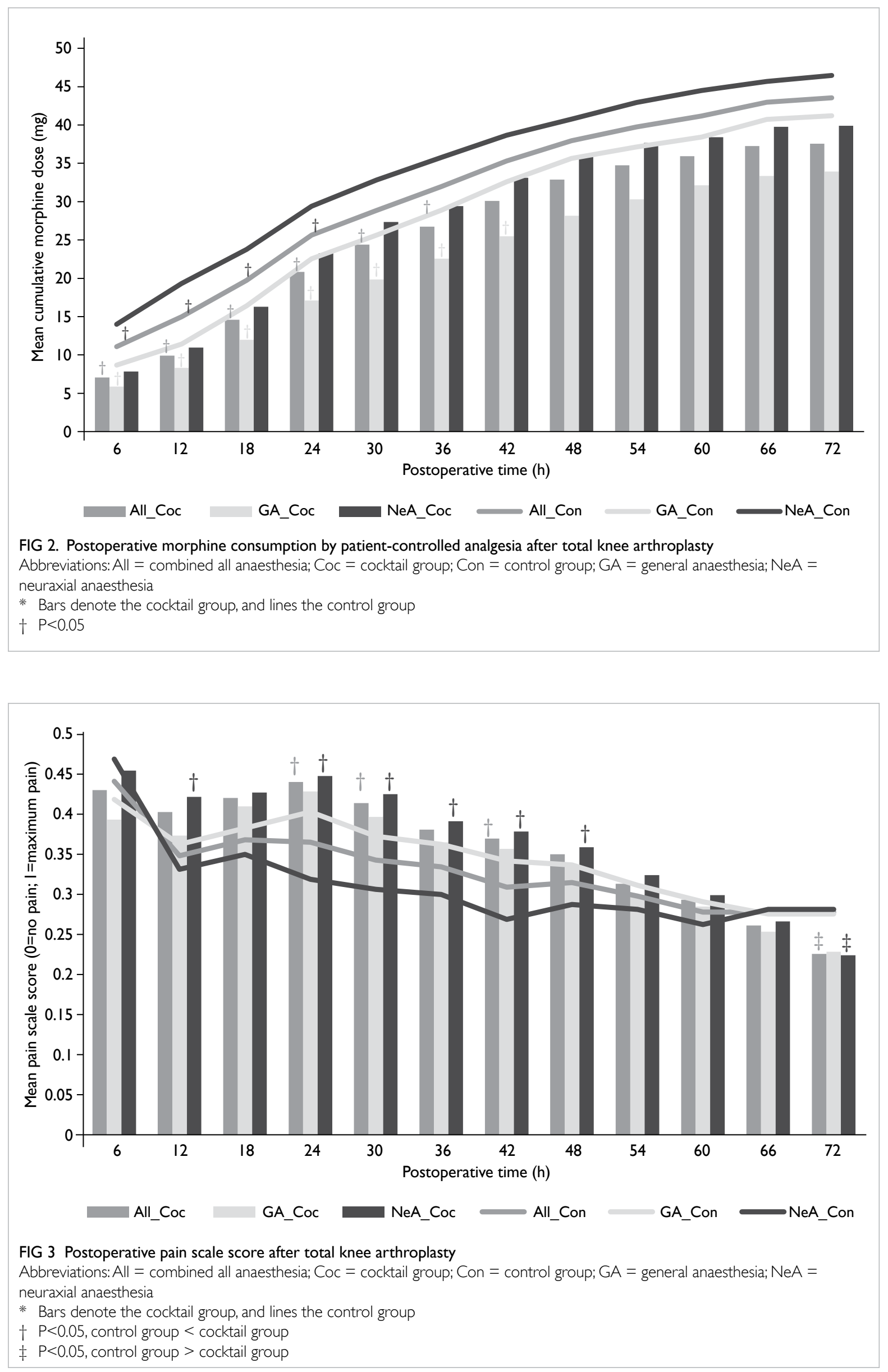
stay. ${ }^{21}$ At the AHNH, $1 \mathrm{~mL}$ of ketorolac $30 \mathrm{mg} / \mathrm{mL}$ has been added to IPMI since July 2014 to provide local anti-inflammatory action and enhance the analgesic effect.

Regional anaesthesia is the preferred method. ${ }^{7,8}$ The previous randomised trials of multimodal drug injection in TKA involved a mixed group of GA and regional anaesthesia, ${ }^{6}$ or excluded the samples of GA..$^{13}$ Randomisation of anaesthesia in clinical trials is unethical because of the obvious benefit of regional anaesthesia that avoids central nervous system depression and prevents deep vein thrombosis following TKA. ${ }^{22} \mathrm{~A}$ retrospective study stratifying different types of anaesthesia is therefore the preferred method, as in the current study. The present study revealed that IPMI in TKA under NeA could significantly decrease PCAMC for 24 hours.

A concordant finding could not be obtained between the effect of IPMI on PCAMC and subjective pain scale. It is possible that the greater use of PCA morphine in the control group in earlier years explained the lower postoperative pain scores. Nonetheless, this could not explain the absence of this phenomenon in the GA subgroup. Rather, it may be explained by the secular change in patient expectations. To many patients early on, TKA was well-known to be associated with a high level of pain. They may have therefore used more PCA morphine. The level of perceived pain was then less than expected with a consequent lower pain score. With increasing popularity of TKA and knowledge of IPMI, patients may have been overly optimistic about the outcome. The 4-point pain scale used in the control group may have exaggerated this discrepancy when one lower grade of pain severity was equal to a 0.25 -drop in pain score compared with a 0.1 -drop in the 10-point pain scale.

Lamplot et $\mathrm{al}^{23}$ reported that the use of periarticular injection and multimodal analgesics could lower pain scores, with fewer adverse effects, lower narcotic usage, higher patient satisfaction, and faster recovery. At the AHNH, TKA protocols for perioperative pain management, blood management, and rehabilitation were altered following the establishment of the Joint Replacement Centre in October 2015. For the pain management protocol, the hospital now uses preemptive oral pregabalin, paracetamol, and etoricoxib if not contra-indicated. The anaesthetist performs a singleinjection femoral nerve block or adductor canal block before anaesthesia. Surgeons deliver IPMI. The postoperative cocktail consists of pregabalin, paracetamol, etoricoxib, and tramadol. The new protocols have made a significant contribution to the improvement in postoperative patient recovery. ${ }^{24,25}$ Further studies will be conducted on the new perioperative analgesic protocol to confirm its efficacy.
There were limitations to this retrospective study, which compared two groups of patients with TKA performed during different periods of time. First, possible secular changes to patient expectations and pain assessment tools might have led to discordant outcomes when IPMI was evaluated. Second, the pain scale did not focus separately on rest pain and motion pain. Third, although the data were selectively verified by the author, there might have been errors in data extraction and coding of other data. Last but not least, because TKAs were performed by more than one surgeon, it was difficult to standardise the intra-operative soft-tissue tension and balancing and the injection technique of IPMI. If the knee was made too tight or IPMI missed the quadriceps tendon, the patient would experience greater postoperative pain.

In conclusion, IPMI effectively decreases parenteral morphine consumption for up to 42 hours following TKA in patients with OA of the knee.

\section{Declaration}

The author has disclosed no conflicts of interest. No funding was received for this study.

\section{References}

1. Bonica JJ. Postoperative pain. In: Bonica JJ, editor. The management of pain. 2nd ed. Philadelphia: Lea and Febiger; 1990: 461-80.

2. Ranawat CS, Ranawat AS, Mehta A. Total knee arthroplasty rehabilitation protocol: what makes the difference? J Arthroplasty 2003;18(3 Suppl 1):27-30.

3. Singelyn FJ, Deyaert M, Joris D, Pendeville E, Gouverneur JM. Effects of intravenous patient-controlled analgesia with morphine, continuous epidural analgesia, and continuous three-in-one block on postoperative pain and knee rehabilitation after unilateral total knee arthroplasty. Anesth Analg 1998;87:88-92.

4. Shoji H, Solomonow M, Yoshino S, D'Ambrosia R, Dabezies E. Factors affecting postoperative flexion in total knee arthroplasty. Orthopedics 1990;13:643-9.

5. Lavernia C, Cardona D, Rossi MD, Lee D. Multimodal pain management and arthrofibrosis. J Arthroplasty 2008;23(6 Suppl 1):74-9.

6. Busch CA, Shore BJ, Bhandari R, et al. Efficacy of periarticular multimodal drug injection in total knee arthroplasty. A randomized trial. J Bone Joint Surg Am 2006;88:959-63.

7. Maheshwari AV, Blum YC, Shekhar L, Ranawat AS, Ranawat CS. Multimodal pain management after total hip and knee arthroplasty at the Ranawat Orthopaedic Center. Clin Orthop Relat Res 2009;467:1418-23.

8. Chu CP, Yap JC, Chen PP, Hung HH. Postoperative outcome in Chinese patients having primary total knee arthroplasty under general anaesthesia/intravenous patient-controlled analgesia compared to spinal-epidural anaesthesia/analgesia. Hong Kong Med J 2006;12:442-7.

9. Lozano LM, Núñez M, Sastre S, Popescu D. Total knee arthroplasty in the context of severe and morbid obesity in adults. Open Obes J 2012;4:1-10. 
10. Ringrose NH, Cross MJ. Femoral nerve block in knee joint surgery. Am J Sports Med 1984;12:398-402.

11. Heard SO, Edwards WT, Ferrari D, et al. Analgesic effect of intraarticular bupivacaine or morphine after arthroscopic knee surgery: a randomized, prospective, double-blind study. Anesth Analg 1992;74:822-6.

12. Woolf CJ, Chong MS. Preemptive analgesia-treating postoperative pain by preventing the establishment of central sensitization. Anesth Analg 1993;77:362-79.

13. Mullaji A, Kanna R, Shetty GM, Chavda V, Singh DP. Efficacy of periarticular injection of bupivacaine, fentanyl, and methylprednisolone in total knee arthroplasty: a prospective, randomized trial. J Arthroplasty 2010;25:8517.

14. Mauerhan DR, Campbell M, Miller JS, Mokris JG, Gregory A, Kiebzak GM. Intra-articular morphine and/ or bupivacaine in the management of pain after total knee arthroplasty. J Arthroplasty 1997;12:546-52.

15. Stein C. The control of pain in peripheral tissue by opioids. N Engl J Med 1995;332:1685-90.

16. Stein C. Peripheral analgesic actions of opioids. J Pain Symptom Manage 1991;6:119-24.

17. Stein C. Peripheral mechanisms of opioid analgesia. Anesth Analg 1993;76:182-91.

18. Leone S, Di Cianni S, Casati A, Fanelli G. Pharmacology, toxicology, and clinical use of new long acting local anesthetics, ropivacaine and levobupivacaine. Acta Biomed 2008;79:92-105.

19. Parvataneni HK, Ranawat AS, Ranawat CS. The use of local periarticular injections in the management of postoperative pain after total hip and knee replacement: a multimodal approach. Instr Course Lect 2007;56:125-31.

20. Parvataneni HK, Shah VP, Howard H, Cole N, Ranawat AS, Ranawat CS. Controlling pain after total hip and knee arthroplasty using a multimodal protocol with local periarticular injections: a prospective randomized study. J Arthoplasty 2007;22(6 Suppl 2):33-8.

21. Andersen KV, Nikolajsen L, Haraldsted V, Odgaard A, Soballe K. Local infiltration analgesia for total knee arthroplasty: should ketorolac be added? Br J Anaesth 2013;111:242-8.

22. Sharrock NE, Haas SB, Hargett MJ, Urquhart B, Insall JN, Scuderi G. Effects of epidural anesthesia on the incidence of deep-vein thrombosis after total knee arthroplasty. J Bone Joint Surg Am 1991;73:502-6.

23. Lamplot JD, Wagner ER, Manning DW. Multimodal pain management in total knee arthroplasty: a prospective randomized controlled trial. J Arthroplasty 2014;29:32934.

24. Ng FY, Ng JK, Chiu KY, Yan CH, Chan CW. Multimodal periarticular injection vs continuous femoral nerve block after total knee arthroplasty: a prospective, crossover, randomized clinical trial. J Arthroplasty 2012;27:1234-8.

25. Wu JW, Wong YC. Elective unilateral total knee replacement using continuous femoral nerve blockade versus conventional patient-controlled analgesia: perioperative patient management based on a multidisciplinary pathway. Hong Kong Med J 2014;20:45-51. 